\title{
FORCES OF CHANGE: THE SCULPTING OF A REFORMER
}

\author{
PAige PATTERson ${ }^{*}$
}

Southwestern Baptist Theological Seminary

\begin{abstract}
With this article, Paige Patterson identifies six events in the life of Martin Luther that shaped the Reformer and ultimately affected the entire Reformation. By surveying Luther's journey to Rome, his friendship with Johann von Staupitz, the Leipzig Disputation, the Diet of Worms, his year in Wartburg Castle, and his marriage to Katharina von Bora, Patterson's goal is for his readers to gain a greater understanding of Martin Luther. In so doing, Patterson encourages his readers to consider the contribution of these events and the people involved to their own lives still today.
\end{abstract}

KEY WORDS: Luther, Reformation, Eck, Staupitz, Katharina von Bora

\section{Introduction}

As I write, an enormous sheet of ice is about to break from the country of Greenland. That is sufficiently dramatic, but gifted scientific minds now attempt to assess why this is happening and what its results will be. Looking out my window here in Costa Rica, I cannot fail to observe the active volcano that towers for thousands of feet above me. While we can identify many of the shaping forces for this rising peak in the midst of the jungle, no one can predict how those forces will eventually shape this volcano. In the same way, the leaders among men bring to their assignments certain abilities and gifts. But beyond their own resources, they are shaped by external events that they never anticipated. And those events contribute to the making of the individual and his life work.

The life and labor of Martin Luther is well known in Europe and to some degree the whole world. A rehearsal of the life of the Reformer would be of little value to readers of this article. Rather, I will focus on six incidents in Luther's life, which I will argue exercised seminal influence on the Augustinian monk and, therefore, on the entire Reformation. In so doing, I recognize that other scholars might select a different constellation of events

* PAIGE PATTERSON (PhD 1973, New Orleans Baptist Theological Seminary) is professor of biblical theology and president of Southwestern Baptist Theological Seminary in Fort Worth, Texas, United States of America. Email: presidentsoffice@swbts.edu. 
and be confident that their position could not be refuted. The claim made here is not for exclusivity but the more modest affirmation that these six events can be shown to have been pivotal in certain monumental ways to the life of Luther. To comprehend them is to gain a significant understanding of the Reformer.

\section{Journey to Rome}

In November of 1510, Luther found himself representing the Augustinian monks of Erfurt in a dispute to be settled by the Pope. Already aware of many of the demands for reform within the church in Rome, Luther nevertheless seized this opportunity with the customary passion of his character. Kneeling as he approached Rome, Luther extoled its virtues. Even though he anticipated evil, he was stunned by the extent of wickedness. In Table Talk, Luther purportedly observed:

I wouldn't take one thousand florins for not having seen Rome because I wouldn't have been able to believe such things if I had been told by somebody without having seen them for myself. We were simply laughed at because we were such pious monks. A Christian was taken to be nothing but a fool. I know priests who said six or seven masses while I said only one. They took money for them and I didn't. In short, there's no disgrace in Italy except to be poor. Murder and theft are still punished a little, for they must do this. Otherwise no sin is too great for them (Luther 1967: 427).

To illustrate this further and to emphasize the debauchery of Rome, Luther told the story of a Jew who wished to become a believer in Christ. However, he expressed to his priest that before he would be baptized, he wished to see Rome. The priest knew that this was a bad idea and demurred, but the Jew insisted. Luther wrote of this account:

And after he had witnessed enough to cause his hair to stand on end he returned to the priest and requested baptism, saying, 'Now I am glad to worship the God of the Christians, for he is sufficiently longsuffering. If he can endure such knavery in Rome he can easily endure all the wickedness in the world. For our God is angry enough to punish us, his people, in various ways' (Luther 1967: 209).

As Luther progressed to the conclusion of his commentary on Romans, he once again contemplated a comparison between the wickedness of biblical Rome and the Rome of his own era. He wrote:

And in 2 Peter 2: 13 we read: 'They count it pleasure to revel in the daytime. They are blots and blemishes, reveling in their dissipation, carousing with you.' But now Rome, having returned to her former morals, draws almost the whole 
world after her in keeping with her example, if the Rome of today does not even exceed ancient Rome in her outgushing of riotousness so that it would seem to demand apostles again, but with even greater urgency. Would that their coming be kindly before they come as judges (Luther 1972: 481).

Roland Bainton suggests that even in moments of arduous devotion, Luther experienced doubts. Climbing on his knees the Scala Santa in the chapel of San Lorenzo, Luther bent to kiss each step where ostensibly the blood of Christ had dropped on Pilate's now transported marble stairs. Arriving at the top, the monk raised himself and said, 'Who knows whether it is so?' (Bainton 1950: 51).

Luther approached Rome with reverence, but the seeds of doubt were already there. What he observed took the tiny seeds of a watermelon and, over time produced a large member of the cucurbitaceae that he could no longer deny. Upon departing from Rome, the Augustinian was not yet prepared to spawn a reformation, but he was thoroughly shaken. He now had reason to wonder if Bernard's assessments that Rome was too far gone to experience a reformation from within itself were correct. These effects were immediate. But the full gravity of the diabolical aspects of what Luther observed in Rome would be abetted by other encounters and provided the seed bed that produced Reformation thinking.

\section{The Vicar of the Augustinian Order}

No assessment of Luther would be adequate without consideration of Johann von Staupitz. Staupitz clearly believed that Luther had much to offer. He must have been struck by Luther's devotion to the austerities of the commitment to the life of a monk. But he was also in what must have seemed like a perpetual conversation with Luther about the agonies of the spirit which the latter encountered. The gnawing guilt that was the constant companion of Luther was countered by Staupitz by the reading of the Word of God. As Heiko Obermann says in his biography of Luther:

The anecdote about Staupitz and his Job sermons evinces a Protestant slant when it concludes: 'The foundations of the Christian faith, so he said, were still hidden from him at that time.' But the heart of the matter is that Staupitz genuinely purged biblical exegesis of cumbersome erudition. Luther's recollection of Staupitz's instructions that only the Bible was to be read in the monastery (probably meaning in the refectory during meals) is in keeping with this. More changed than style when Staupitz put aside the discussion of Gregory the Great and Thomas Aquinas and reached for the Scriptures. What remained was the subject: God's mercy, the refuge Job seeks in his suffering. This divine mercy becomes even more palpable and develops an exceptionally personal appeal in Staupitz's principal work, the 1516 Nuremburg Advent sermons. Christ, who suffered and was crucified, is the guarantee for a merciful God. 'I' can see from 
Christ, who died 'for me' and lives 'in me', that God has turned his countenance to me (Obermann 1982: 181).

Bainton correctly observes that 'light broke at last through the examinations of exact shades of meaning in the Greek language' (Bainton 1950: 64). He goes on to explain this as reasoning for why Luther could never disdain the humanist tools of scholarship. Luther believed that the languages of the Scripture as originally given were essential to the theologian and stupendously helpful to the preacher. Luther even employed the language of new birth to describe his discovery:

Night and day I pondered until I saw the connection between the justice of God and the statement that 'the just shall live by his faith'. Then I grasped that the justice of God is that righteousness by which through grace and sheer mercy God justifies us through faith. Thereupon I felt myself to be reborn and to have gone through open doors into paradise (Bainton 1950: 65).

Luther's description of why he needed to feel estrangement from God, being drawn not only to repentance but also to faith in the work of Christ on the cross, constitutes as clear a statement of the new birth as one could find in the literature of the two Great Awakenings in America. In the end, no other event of Luther's life carries the import of this experience. The remainder of his life and the Reformation itself depend on the sense of God's love and grace extended to Luther at this moment.

\section{The Leipzig Disputation}

The roots of doubt had been sown in Luther's mind by the pilgrimage to Rome. Personal doubts about his standing with God had been ameliorated by the reading of the Bible until he understood and experienced justification in his own heart. But he was still a Roman Catholic in many ways. If he had come to doubt the authority of the Pope, and even though he now proclaimed the authority of the Bible, Luther remained confident also in the authority of conciliar definition. Having displayed his ninety-five theses in 1517 , it seems odd that he would still maintain adherence to the Council. July 4-14, 1519, would alter this conclusion when John Eck, the colorful and skillful debater from Ingolstadt, faced Luther at Leipzig. Balthasar Hubmaier, the lone Anabaptist to boast a doctorate, had studied at Ingolstadt with Eck. Hubmaier's proclivities in debate show the influence of his mentor. Again, Roland Bainton's description of Eck sums up the matter nicely:

Despite his butcher's face and bull's voice he was a man of prodigious memory, torrential fluency, and uncanny acumen-a professional disputant who would 
post to Vienna or Bologna to debate the works of the Trinity, the substance of angels, or the contract of usury. Particularly exasperating was his propensity for clothing the opprobrious with plausibility and driving an opponent to incriminating conclusions (Bainton 1950: 107).

John Stoughton paints Eck in similar fashion:

Eck was tall and broad-shouldered, and had a strong German voice, 'fit for the stage-fit for a public crier'. His accentuation was thick, rather than distinct. His mouth, eyes, and countenance gave the impression of his being a soldier or a butcher, rather than a divine. This description proceeds from no friendly pen; and Eck is further painted as slow of comprehension and defective in judgment, and as a man of inconceivable impudence; but he is credited with an excellent memory, which enabled him to heap passage on passage from the Fathers, with a perseverance which must have been perplexing to his opponents (Stoughton 1903: 109).

At the right moment, Eck introduced the charge that Luther was infected with the virus of Hus. Luther strenuously objected that he was not a part of Bohemianism. Luther, stung but intrigued by the charge, investigated it further. His conclusion was that 'We are all Hussites without knowing it'. The critical nature of this discovery at the prodding of the belligerent Eck is that Luther now invoked the doctrine of biblical authority alone in matters of faith. The Bible was now to be placed even above conciliar judgment. Luther had now moved from having doubts about Rome, to a personal conversion, and finally to a rejection of the Roman curia in favor of the Bible.

\section{The Diet of Worms}

In the heart of the city of Worms stands a bronze of Martin Luther, Bible in hand. He is surrounded by precursors of the Reformation: John Hus, John Wycliffe, Peter Waldo, and Girolamo Savonarola. The magnificent monument depicts the Reformation but especially the Diet of Worms, which was convened in January of 1521. The significance of Worms has been enunciated by Andrew Pettegree:

In the two years 1518 and 1519 Luther's world changed out of all recognition. He became a public figure. He became, to his distress, the enemy of the church he had served so faithfully for his first thirty-five years. He began to attract passionate devotion beyond the small number of intimates who had thus far shared his cause. And he became a best-selling author (Pettegree 2015: 87).

The arrival of Luther into Worms was irritating to some members of government and certainly to the Roman Catholics. It was as though a hero, ra- 
ther than a heretic, had arrived. Richard Friedenthal described some of the scene:

People, their curiosity aroused, had ridden out to meet the heretic; the imperial herald, his cloak emblazoned with the emperor's coat-of-arms thrown over his arm, preceded him to let everyone know that Luther was travelling under protection of the emperor's safe conduct. The streets filled with people. The procession had difficulty in making its way to the hospice of the Knights of St John, where Luther was to stay; it was near the Swan Inn, where the elector of Saxony had his lodgings. The heretic took his midday lunch with ten or twelve other people; his room was never free of visitors who came to encourage him, frighten him, or merely to see him (Friedenthal 1967: 273).

Few could have anticipated the dramatic end of the proceedings. The culmination of the years of spiritual struggle in the monastery, the odyssey to Rome, the conversion to evangelical Christianity, and the discovery to which Luther had been forced at Leipzig all suddenly burst on the Diet when Luther replied to an admonition in the now often repeated statement:

Without horns and without teeth... unless I am convinced by testimony from the Holy Scriptures and clear proofs based on reason-because, since it is notorious that they have erred and contradicted themselves, I cannot believe either the pope or the Council alone-I am bound by my conscience and the Word of God. Therefore, I can and will recant nothing, because to act against one's conscience is neither safe nor salutary. So help me God (Friedenthal 1967: 278).

There is a sense in which the Reformation was born in 1517 with the nailing of the theses to the chapel door in Wittenberg. Few would contest this conclusion. But I suggest that the Diet of Worms may be the better candidate for the beginning of the Reformation. At least it was here that a full declaration of epistemology was established as the track for the Reformation. Humbly, but boldly, Luther had stated that to the best of his ability to understand, he would follow nothing but the Bible. However inconsistently that noble goal might be pursued and whatever the debates be that would soon arise among Protestants, this rule belonged neither to Pope, nor council or church, but to the Word of God.

\section{Wartburg Castle}

More than any other of Luther's biographers, Heiko Obermann focuses on the prominent role of the devil in the thinking of Luther. And he is not in error to do so even though the preeminence of Christ in the war waged with Satan is lucidly present in Luther's thinking. This is nowhere more clearly observed than in the months following his time at Worms. At the conclusion of the Diet, the world was no longer safe for Luther. He could 
not even trust friends to remain faithful. But some were loyal; and, fearing for Luther's life, these men took him to the safety of Wartburg Castle. It remains today as a monument to Luther and now hosts a luxury hotel where one can observe the beauty of the forest while reliving those fateful events.

Luther's existence was not traumatic in some ways. He was relatively safe. He had enough to eat and he taught regularly. But his monastic days were over. He longed for Wittenberg and the classroom. He needed more complete news coverage than was available in the castle. He penned letters to friends from 'my isle of Patmos'. And he fought daily with the devil. Sometimes, he was able to secure victory only by reliving his conversion to Christ. He began his isolation in Wartburg on May 4, 1521, and with only one major intervention did not depart until March of 1522. Why then would this be considered a pivotal time in Luther's life?

While in Wartburg, Luther completed his translation of the New Testament into German. Bainton suggests that Luther thought that the Reformation flew on the wings of his books. While intending no lack of appreciation for Luther's books, Bainton believed that the Reformation proceeded principally under the auspices of Luther's German Bible and on political and religious cartoons, which at the time dotted the landscape of Europe and could be grasped by just about everyone. If he is correct, then the months at Wartburg are filled with new meaning and have become essential to the life of Luther and to the Reformation. As Latourette observed, 'Through his translation of the Bible into German, a version which the movement that began with him made standard, and through his other writings, Luther did much to establish a common form of the German tongue for speech and writing' (Latourette 1967: 415).

With the Bible in their own language, more and more Germans began to read. New printing presses made Bibles and other books more readily available. The Protestant cause triumphed as the common man encountered the Word of God.

\section{Marriage}

While in Wartburg, Luther teased with Melanchthon that it was he who was responsible for the forced exile. Luther suggested that it was for the purpose of forcing him to marry since he had apparently urged Melanchthon to do so. Undoubtedly, Luther had given some thought to marriage. But he anticipated a martyr's death and did not want to leave behind a grieving widow and children. And besides, he had been a monk too long and the idea of sleeping with a wife was not easily digested. However, there was

quite a line of those who attempted to secure a wife for Luther. And why 
should one expect that the matter of marriage should be anything other than full of drama for such a man?

Therefore the story of twelve nuns smuggled from a convent via the use of fish barrels can hardly be surprising. After a while, Katherine von Bora of Torgau, the picturesque town where Luther loved to visit in later years, was the only one of those nuns left without a husband. Luther made at least one concentrated effort to arrange a marriage for her, but Katie had already laid her eyes on Luther. Finally, Luther acquiesced. But why, once again, should this rank as one of the more significant developments in the rolling sea of Luther's life? First, as was indicated in the introduction, Katie changed Luther, and that most notably for the good. Sometimes, however, in Table Talk he would complain a bit. For example, Luther is recorded to have said:

Man has strange thoughts the first year of marriage. When sitting at table he thinks, 'Before I was alone; now there are two.' Or in bed, when he wakes up, he sees a pair of pigtails lying beside him which he hadn't seen there before. On the other hand, wives bring to their husbands, no matter how busy they may be, a multitude of trivial matters. So my Katie used to sit next to me at first while I was studying hard and would spin and ask, 'Doctor, is the grandmaster the margraves' brother?' (Luther 1967: 191).

But on the whole, Luther became increasingly positive about marriage as he grew in dependency on Katie. He might call her Kette, 'my chain', but he had little desire to be far from her. In fact, the two superbly complemented each other. In addition to his own family, Luther almost always had guests. Katie was the epitome of hospitality. The two shared the duties of the home, each presiding over that appealing to their respective giftedness.

Luther was mercurial. When attacked by the devil or racked with sickness, he could suffer depression. Katie had the capacity to rise above this and to brighten the day for the gloomy preacher. So as Luther assessed his marriage, he is reported to have observed:

Marriage consists of these things: the natural desire for sex, the bringing to life of offspring, and life together with mutual fidelity. Yet the devil can so rupture marriage that hate is never more bitter than here. This comes from our beginning everything without prayer and with presumption. A God-fearing young man who is about to be married should pray, 'Dear God, add thy blessing!' (Luther 1967: 25).

Bernhard Lohse observes:

Luther personally, however, saw his action as primarily an act of faith in opposition to the devil and all apocalyptic expectation. In addition, Luther had decided 
to marry after very carefully thinking through the situation and he carried out his intention in a very deliberate way. This was not a marriage of love in the modern sense of the term. Ever since the monks had gradually deserted the cloister in which he lived, and the monastic community had been gradually dissolved, Luther basically had taken care of himself. By 1525, he badly needed someone who would take charge of the household and see that Luther himself was taken care of (Lohse 1980: 33).

We can only conclude that without Katie, whom he came to love passionately, Luther would not have developed portions of his character essential to the progress of the Reformation. Furthermore, his example was enhanced through this marriage and the care for his own children.

\section{Conclusion}

The articulation of these six events, which shaped the Reformer and prepared him for his ministry, is admittedly arbitrary. A dozen others could have been selected. But these six events are sufficient to remind us that in all of our work, we are the products of others whose lives so impact our own that we without them are less effective than would otherwise be the case. Luther, for all his achievements and with all of his significance, was the product of the people and events described briefly herein. As we give thanks to God for the Reformer, so we should thank God for a sometimes bewildered Staupitz, an impudent Eck, a loving Katie, and many others who unwittingly or purposefully contributed.

\section{Bibliography}

Bainton R (1950) Here I Stand: A Life of Martin Luther. Nashville, TN: Abingdon Press.

Friedenthal R (1967) Luther. London: Weidenfeld and Nicolson.

Latourette KS (1967) A History of the Expansion of Christianity: Three Centuries of Advance. In Contemporary Evangelical Perspectives, volume 3. Grand Rapids, MI: Zondervan.

Luther M (1967) Table Talk. In Lehmann HT (ed) Luther's Works, volume 54. Philadelphia, PA: Fortress Press.

Luther M (1972) Lectures on Romans. In Oswald HC (ed) Luther's Works, volume 25. Saint Louis, MO: Concordia Publishing House.

Lohse B (2009) Martin Luther: An Introduction to His Life and Work. Grove City, OH: Augsburg Fortress.

Oberman HA (1989) Luther: Man between God and the Devil. New Haven, CT: Yale University Press.

Pettegree A (2015) Brand Luther: 1517, Printing, and the Making of the Reformation. New York, NY: Penguin Press. 
Stoughton J (1903) The Homes and Haunts of Luther. London: The Religious Tract Society. 